PRIMCED Discussion Paper Series, No. 14

\title{
Participatory Rural Development in 1930s Japan: The Economic Rehabilitation Movement
}

\author{
Yutaka Arimoto
}

September 2011

Research Project PRI MCED

Institute of Economic Research

Hitotsubashi University

2-1 Naka, Kunitatchi Tokyo, 186-8601 Japan 


\title{
Participatory Rural Development in 1930s Japan: The Economic Rehabilitation Movement
}

\author{
Yutaka Arimoto*
}

July 1, 2011

Short running head: Participatory development in 1930s Japan

\begin{abstract}
Abs tract
This paper studies an early participatory rural development program implemented during the 1930s in Japan. This program selected several villages each year to draft and implement their own original development plans. I discuss the implications of the features of the program on its effectiveness. A detailed baseline survey conducted by the villagers themselves helped them to objectively diagnose their economic situations and understand their issues. The plans defined clear numerical targets, allowing them to share goals and monitor progress. The implementation of the plan was reinforced by frequent communication and monitoring among neighbors and by an incentive scheme that involved competition within a village. I use a village-level panel dataset from the Hyogo prefecture to examine the effects, under the difference-in-differences strategy. I find suggestive evidence that the program helped foster the adoption of cattle raising and diversify agricultural production.
\end{abstract}

Keywords: Participatory development, Rural development program, Crop diversification, Great Depression, Japan

JEL classification: O10, N55, R58

*Institute of Economic Research, Hitotsubashi Univers ity, 2-1 Naka, Kunitachi, Tokyo 186-8603, Japan. Tel: +81-42-580-8346. Email: arimotoy@ier.hit-u.ac.jp. 


\section{Introduction}

Improving livelihoods in the rural sector is a premise of economic development and social stability. The rural sector plays a vital role in a country's economy by supplying food and labor for the industrial sector. Once rural incomes begin to rise, the rural population also serves as a driver of industrialization by demanding industrial products. Therefore, many countries put considerable effort into promoting social and economic development in rural areas, often by conducting various rural development programs. In conducting such programs, recent interventions are placing considerable emphasis on the participation and empowerment of beneficiary communities (World Bank, 2005; Binswanger-Mkhize, de Regt, and Spector, 2010).

This paper studies a policy introduced in Japan during the 1930s, which was probably the earliest, nation-wide, participatory rural development program ${ }^{2}$. The program, namely, the Economic Rehabilitation Movement (ERM) (keizai kosei undo), aimed at helping the recovery of rural villages that was seriously damaged by the Great Depression. It was a thorough bottom-up, participatory program in which the selected villages were responsible for drafting and implementing their own original development plans. The program also had a number of unique features that seemed to improve its effectiveness. This case provides useful insights into how Japan responded to an unprecedented depression, how the policy was intended to involve community initiatives, and how well it worked in aiding in the recovery.

The purpose of this paper is to re-evaluate the ERM as a rural development program and to examine its effect quantitatively. To this end, I first describe the features of the ERM as a participatory development program and discuss how some of its features might have served to enhance the effectiveness of the program. I then use a village-level panel dataset from the Hyogo prefecture from the years 1930, 1935, and 1940 in order to analyze the effects of the ERM. The data span over the periods before and after the introduction of the program, which allows me to use a difference-in-differences strategy to evaluate the impact.

Previous studies of the ERM are mostly historical and have focused much on its political and ideological aspects ${ }^{3}$. A common understanding is that the movement formed a basis for fascism by organizing rural communities to supply food and troops for the state, in the name of

\footnotetext{
2 According to Binswanger-Mkhize, de Regt, and Spector (2010), Bangladesh and India first implemented programs that advanced community roles, in the 1940s. The implementation of the ERM in Japan started in 1932.

${ }^{3}$ For a review of historical ERM studies, see Takahashi (1997).
} 
rural rehabilitation and relief (Takahashi, 1997). On the other hand, little is known regarding the economic effects of the ERM. Only a few descriptive studies examine the ERM from the perspective of economic and rural development policy (e.g., Godo, 1995; Hatta, 1996; Okada, 1989). The Ministry of Agriculture and Forestry (MAF; 1933, 1935, 1936, and 1938) and some prefecture governments published reports that introduced some "best practice" cases; although these reports are informative in that they allow us to know how the movement was implemented and what the plans were like, their appraisals of "success" tend to be self-serving. Given that the majority of the villages received only a trivial subsidy, previous studies have claimed that the ERM had no tangible economic effect and have ended up as merely an ideological movement with an empty slogan without any appropriate quantitative evaluation (Inoue 1957, Mori 1998). This paper is, to the best of my knowledge, the first examination of the effect of the ERM, based on the comparisons of the outcomes of those villages selected to participate in the program and those that were not ${ }^{4}$.

I find that the villages selected for the ERM were successful in terms of two key recovery strategies: the diversification of agricultural production and the introduction of cattle raising. Indeed, some subgroups of the participating villages increased the percentage of cattle-raising farm households by approximately 5.7-6.5\%, and their agricultural diversification index values increased by $2.8 \%$. I also obtained suggestive evidence that participation in the ERM was beneficial in terms of income improvement and debt reduction. The empirical results suggest that the ERM had some real effects on the rural economy, beyond the political and ideological, despite the lack of financial support.

I argue that some of the unique features of the ERM were keys to the effectiveness of the program. For example, participating villages were required to conduct a detailed baseline household survey. This was indispensable for the villagers in objectively diagnosing their current economic situations and finding appropriate solutions for the issues they faced. The plans defined clear numerical targets, and the villagers were able to share and monitor their progress. The actual implementation of the plan was borne by small implementation groups consisting of closely related neighbors who could frequently communicate with and monitor each other. The ERM's execution was reinforced by holding a competition among the

\footnotetext{
${ }^{4}$ The exception is Kamiya (1937), which compares population growth between the selected and non-selected villages.
} 
communities in terms of the achievement of planned goals. These organizational and incentive structures of the program also seemed to have certain implications on the actual implementation of the plans.

The remainder of the paper is organized as follows. Section 2 provides an overview of the ERM in the Hyogo prefecture. I discuss in detail the features of the program and their implications on the ERM's effectiveness in detail. Section 3 presents the data and measurement strategy. Section 4 examines the determinants for the selection to the program. Section 5 analyzes the effect of the program and discusses some concerns on the over-estimation of the effect. I conclude with Section 6.

\section{The Economic Rehabilitation Movement}

\subsection{Overview}

The ERM was introduced in 1932 as a relief policy against the Great Depression, which began in October 1929. Rural economies were hit by drastic price drops in main agricultural produce, especially rice and cocoons. Accordingly, farmers' debt was believed to have reached an amount that was nearly twice the average household's annual income. In August 1932, the $63^{\text {rd }}$ Extraordinary Imperial Diet Session, referred to as the "rural relief diet," was held; a budget for the ERM was passed, along with public relief projects and price supports for rice.

The goal of the ERM was to support rural villages in their recovery from economic downturn, by improving income, reducing the costs of living and production, and liquidating accumulated debts. The essence of the ERM was to prompt villages to draft and implement their own rehabilitation plans. In each prefecture, several villages were selected every year as "rehabilitation villages" (kosei-son). Each of the selected villages was required to establish an economic rehabilitation committee, conduct a baseline survey, diagnose its situation, and establish its own economic rehabilitation plans. Upon selection, each village was granted a one-time subsidy of 100 yen $^{5}$. However, this subsidy was negligible ${ }^{6}$. In order to assist villages that lacked the budget to implement their plans, the Special Subsidy Program (SSP; tokubetsu josei) began from 1936, and it granted substantial subs idies amounting to an average of 15,000 yen per village. Therefore, the ERM had two pillars: the planning of a rehabilitation plan and

\footnotetext{
${ }^{5}$ In Hyogo prefecture, the subsidy was 200 yen per village.

${ }^{6}$ By way of comparison, the annual income of a farm household at that same time was approximately 500 yen.
} 
disbursement of a special subsidy. Overall, the selection for planning began in 1932 and ended in 1940. A total of 9,149 villages (i.e., 83\% of all the villages in the country) had been selected. The SSP began in 1936 and ended in 1941, aiding 1,595 villages (i.e., 17\% of the villages) that had been selected for planning.

Figure 1 depicts the administrative procedure of the ERM in Hyogo prefecture (Hyogo Prefecture, 1938). In Hyogo, the prefectural ERM committee selected up to 40 villages each year, except for in 1932, in which 20 villages were selected. The application was voluntary and the villages willing to be selected were required to submit action and budget plans to the governor. Unfortunately, the criteria for the selection of "rehabilitation villages" are not clear. I examine the possible determinants of selection in Section 4. On the other hand, the eligibility criteria for receiving a special subsidy were very clear: a village was required to (1) have already established a rehabilitation plan at least one year in advance, (2) have a shortage of funds in implementing its plan, and (3) have a strong leader (chushin jinbutsu).

\subsection{Features of the Economic Rehabilitation Movement}

I discuss three features of the ERM that make it unique as a rural development program, and which seem to enhance the effectiveness of the program.

First, the ERM was a thorough participatory, bottom-up program ${ }^{7}$. The guiding principle of the ERM was self-help: the villages were required to recover on their own through "mutual help among residents." The villages were responsible throughout the entire process for conducting the baseline survey, and drafting and implementing the rehabilitation plan. In this respect, the movement shares the same key idea that is part of today's participatory development programs. For example, the World Bank’s community-driven development (CDD) programs emphasize beneficiary participation and give local communities control over project planning and decision-making (Mansuri and Rao, 2004; World Bank, 2005) ${ }^{8}$. The ERM is also similar to

\footnotetext{
${ }^{7}$ We should note, however, that the MAF and prefecture governments provided a format and guidance for the content of the baseline surveys and rehabilitation plans (Hiraga, 2003: ch.3; Yasutomi, 1994: ch.5). There are also indications that because village officials lacked the know ledge and experience needed to draft such plans, some had merely been copied from the prototype. Thus, some villages may have had only limited freedom in drafting their respective plans.

${ }^{8}$ The motive for promoting beneficiary participation, however, seems to differ between the ERM and CDD. The CDD programs delegate control to the local communities, in order to
} 
the CDD in its use of inter-village competition for funding. A typical implementation of CDD projects consists of a limited amount of social funds for which communities can apply by submitting a proposal for a small-scale development program. From these applications, a few are selected to receive funds (Jack, 2001; Rawlings, Sherburne-Benz, and Van Domelen, 2004). This competitive structure may motivate applicants to improve their proposals. The ERM featured a similar competition structure, and only a few villages were selected each year.

The second feature of the ERM was the requirement that an applicant village conduct its own baseline survey. The survey seemed to be effective in enabling villagers to objectively understand their economic situation. The contents of these surveys were similar to a typical survey that a development economist would carry out today. It covered topics such as the labor situations (the situation of those hiring and hired, seasonal shortages and surpluses of labor), the use of agricultural inputs (use of self-supplied fertilizer and purchased fertilizer), agricultural production and sales, and financial status (debt and savings) ${ }^{9}$. The survey was detailed and structured. For example, the labor module of the questionnaire asked monthly information of number of workers required for each crop and how it was managed (i.e., by family labor or hired labor). In this way, villages were able to clarify the seasonal fluctuations in their labor shortages and surpluses ${ }^{10}$. The financial status module was similar to an income/expenditure module of a typical household survey questionnaire. With information regarding the amounts of each income and expenditure items, many rehabilitation plans set a target amount on the reduction of redundant expenditures, such as ceremonial expenses ${ }^{11}$.

The third feature of the ERM was the organizational and incentive structures that were used to implement the rehabilitation plan. A critical organizational feature was that although the

enhance ownership, elicit local needs, and improve the targeting of benefic iaries (Mansuri and Rao, 2004). On the other hand, the ERM’s self-help principle was based on the policymakers' recognition that the villages were relying excessively on the government (Kodaira, 1932).

${ }^{9}$ The survey content was laid down in the format provided by the MAF; the Hyogo prefecture provided a sample form that the survey participants could fill in.

${ }^{10}$ For example, the survey of Shijimi village in Mino County revealed that the only month with a labor shortage was November (i.e., the harvesting season) (Hyogo Prefecture, 1937a). Labor surpluses, on the other hand, were at their peak in September, amounting to over 33,000 man-days of idle workforce.

${ }^{11}$ Kitatani village in Mino County defined target percentages for expenditure cuts: $5 \%$ cuts to current expenditures and $40 \%$ reduction in extra expenses, such as those pertaining to ceremonies (Hyogo Prefecture, 1937a). 
plan was drafted at the village level, its actual execution was borne by small implementation groups at a lower, community level (i.e., a village was comprised of several communities). Since a community consisted of smaller numbers of closely related neighbors, this organizational structure was effective in fostering frequent communication and regular monitoring of progress. This structure was also suitable for providing incentives to implement the plan; many villages held a competition where the communities within the village competed in terms of plan achievements ${ }^{12}$.

\subsection{Strategies for rehabilitation}

I now turn to discuss the contents of the rehabilitation plans. Recall that the main objective of the ERM was to foster recovery from the Great Depression by improving income and reducing accumulated debt. In this context, the following question arises: what kind of strategies did the villages develop to achieve this goal? In order to consider the possible options for raising farmer incomes, note that it is necessary to increase at least one of the following three income components: farm income from main crops, farm income from subsidiary crops, and non-farm income. Among these, the only realistic option was to increase the subsidiary farm income, given that the price of the two main crops (i.e., rice and cocoons) had bottomed out, and that the non-agricultural economy had also been hit by the Great Depression.

Under such circumstances, it is no wonder that many villages focused on the diversification in agricultural production, adoption of animal husbandry, and introduction of side jobs such as handicraft production or small-scale manufacturing ${ }^{13}$. Note that these are

12 The example of Yamada village in Kanzaki County is informative (Hyogo Prefecture, 1937a). This village planned to recover by increasing its production of rush mats. In order to stimulate production, the village periodically held a competition among communities with respect to their sales volumes, wherein awards were given to the top three communities. The village also awarded the community that saw the greatest increase in production since the previous competition, in order to encourage low-performance communities to improve.

${ }^{13}$ Other major plan contents included: the use of village agricultural cooperatives for the collective purchase of inputs and sale of produce, lifestyle improvements (e.g., promotion of savings, book-keeping, self-production of daily goods, reductions in ceremonial expenses, the joint use of instruments and equipment, improvements in hygiene and disaster prevention, and the fostering of mutual relief), and debt liquidation (e.g., setting a debt recourse plan and establishing a debt-liquidation association). The MAF also strongly required the incorporation of ethical reclamation that supported certain ideologies, such as respect for ancestors, prudence, solidarity, social contributions, and mutual help; it is perhaps for this reason that historical 
standard means of improving rural income, even today (which implies that there is no "magic bullet”) ${ }^{14}$. In fact, production diversification and introduction of side jobs were feasible, given that the baseline surveys had revealed that the seasonal surplus labor in the slack season was substantial. Introducing an additional crop was expected to make the best use of idle labor and generate additional income. Furthermore, the MAF promoted the raising of livestock to introduce animal power into plowing, reduce production costs by replacing purchased fertilizer with manure, and raise prof its from selling the livestock itself.

The selected villages were required to write down the quantitative goals of each component of the rehabilitation strategy in the plan (e.g., the target acreage of each crop and number of livestock). With these explic it targets, the villagers were able to share the goals and objectively monitor the ir progress.

\section{Effects of the ERM}

This section examines the economic effects of the ERM. I first describe the data. Then I discuss the determinants of program participation (i.e., selection). Finally, I examine the effects on household income and diversification in agricultural production.

\subsection{Data}

I use village-level data from the Annual Statistics of the Hyogo Prefecture and the National Census for 1930, 1935, and 1940. Figure 2 describes the sample. In Hyogo, the selection of villages for planning (i.e., establishing the rehabilitation plan) started in 1932 and ended in 1938. Of 385 villages, ${ }^{15} 84$ were selected in period 1 (1930-1934) of my dataset, which I refer to as PLAN1. Of the remaining 301 non-PLAN1 villages, 144 were selected during period 2 (1935-1949), which I refer to as PLAN2. Selection for SSP started in 1936 and ended in 1941. Of 84 PLAN1 villages, 26 were selected for SSP during period 2. Five PLAN2

studies have focused on the ideological aspects of the ERM.

${ }^{14}$ Standard strategies of raising rural income include improving the productivity of main crops, diversifying agricultural production by introducing high-value cash crops, livestock, or dairy, exploring off-farm income opportunities, and migration (World Bank, 2007).

${ }^{15}$ I use the village border in 1940 in order to account for the mergers that took place during the study period. Cities (shi) (e.g., Kobe, Himeji, Amagasaki, Akashi, Nishinomiya, Sumoto, Harima, Ashiya, and Itami) are excluded, since they were beyond the scope of the ERM. No towns or villages that were selected for the ERM had been merged into cities by 1940 . 
villages were selected for SSP during period 2, and another six were selected after period 2.

\subsection{Determinants of program participation}

First, I investigated the determinants of selection for planning and a special subsidy for examining whether the characteristics of treated and non-treated villages differed. It is important to note that selection for the ERM was based on two phases of selection: each village first applied voluntarily (self-selection), and then these applicants were further selected by the prefecture.

Table 1 presents the mean differences in pre-treatment village characteristics between the treated and non-treated villages. Panel A compares the pre-treatment means between PLAN1 and non-PLAN1 in 1930; Panel B compares the pre-treatment means between PLAN2 and non-PLAN2 (conditional on being non-PLAN1) in 1935; and Panel C compares pre-treatment means between SSP and non-SSP (conditional on being PLAN1) in 1935.

Panels A and B in Table 1 show that villages selected for planning were more likely to be rural and oriented to agriculture. I find that the non-treated villages tended to have larger populations; this is because some of the non-treated villages were located next to cities, such as Nishinomiya or Amagasaki, which had experienced significant in-migrations during this period. On the other hand, the treated villages tended to rely heavily on agriculture: these villages had a higher percentage of farm households, full-time farmers, owner-cultivators, and owner-cum-tenants than the non-treated villages. As for the outcome variables of interest, they do not significantly differ in terms of crop diversification; this implies that prior to selection, the villages were roughly on the same level before the selection. However, I did find that the percentage of farm households raising cattle was already higher for treated villages.

Contrary to the selection process, Panel C indicates that SSP and non-SSP villages were more or less similar except for population and the number of households. This is probably because the sample (PLAN1 villages) had already been selected through participation in planning. In other words, the selection for SSP was not likely to be based on these observable characteristics.

These observations can be confirmed using probit estimations, which regress the treatment indicators on various pre-treatment village characteristics (Table 2). The independent variables are the same as those for Table 1, except that I dropped the population and number of 
households because they are highly collinear, and the latter is represented by the number of farm households and its percentage among all households. Although the direction of a correlation between dependent and independent variables generally aligned with the observations in Table 1 , most of the coefficients are not precisely estimated after controlling for other variables.

In summary, it is likely that relatively agriculturally oriented villages were selected for the ERM. Unfortunately, due to a lack of data pertaining to program applications, I am unable to examine whether these villages were more likely to self-select for application or if the prefecture was selective in favoring these villages.

\subsection{Effects on household income, expenditure, and debt}

Since the ultimate goal of the ERM was to prompt recovery from the Great Depression, we wish to see whether these impacts coincided with an increase in income or a reduction of debt. Unfortunately, no data in the Annual Statistics of Hyogo Prefecture reflected these outcomes; however, some data before and after the selection for treated villages are available through reports published by the Hyogo Prefecture. According to the Hyogo Prefecture (1937 a, b), which provided data for 10 villages that had been selected for planning, farm income had increased by an average of 399.91 yen before and after treatment, whereas expenditures had only increased by 180.42 yen, resulting in a net increase of 219.50 yen. As for debt, Hyogo Prefecture (1938) provided the data with respect to the change in savings and debt for the period between the year that the rehabilitation plan was established and October 1937 for the 114 villages that had been selected for the ERM between 1932 and 1936. On average, these villages increased savings by 7 percentage points and decreased debt by 13.9 percentage points. These results are suggestive in that they demonstrate that the ERM had some positive outcomes on financial status at the household level. However, we should be aware that the evidence derived only from before-after comparisons; therefore, it could have suffered from selection bias.

\subsection{Effects on diversification}

Here, I examine the effect of the ERM on the diversification of agricultural production and adoption of animal husbandry. As discussed in section 2.3, although the selected villages had been able to draft certain strategies or goals into their rehabilitation plans, these two outcomes seemed to be most realistic (and measurable) under certain social circumstances and 
whenever there was a lack of financial support needed to implement the plan.

I measure the extent of production diversification by the following diversification index:

$$
D I_{i}=1-\sum_{i k}\left(\frac{a_{i k}}{\sum_{k} a_{i k}}\right)^{2}
$$

where $a_{i k}$ is the area cultivated under crop $k$ in village $i$. If $D I_{i}$ is close to 0 , then it implies that production is concentrated in a few crops, whereas a $D I_{i}$ of close to 1 implies diversification. I use planted areas of rice, barley, wheat, naked barley, soybeans, azuki beans, sweet potato, potato, horse bean, cucumber, watermelon, eggplant, daikon radish, aroid, and onion to calculate this index. These crops are selected for this study owing to the following reasons: they occupied high shares of planted areas, they were cultivated in many villages, and longitudinal data for these crops were available for 1930, 1935, and 1940. Regarding the adoption of animal husbandry, I examine the percentage of farm households ${ }^{16}$ that raised cattle, pigs, and horses ${ }^{17}$. Whenever data are available, the percentage of part-time farmers is also considered in order to examine income diversification resulting from non-farm occupations.

I adopt a difference-in-differences approach to estimate the effect of the ERM, using the following regression model:

$$
\begin{aligned}
\Delta y_{i t}=\alpha & +\beta_{1} P L A N 1_{i} \times Y 1935+\beta_{2} P L A N 1_{i} \times Y 1940+\beta_{3} P L A N 2_{i} \times Y 1940 \\
& +\gamma_{1} P L A N 1_{i} \times S S P_{i} \times Y 1940+\delta_{1} P L A N 1_{i} \times S S P_{i} \times Y 1935 \\
& +\delta_{2} P L A N 2_{i} \times Y 1935+\lambda \Delta X_{i}+Y 1940+\Delta \varepsilon_{i t}
\end{aligned}
$$

where $\Delta y_{i t}$ is the change of outcomes for village $i$ between years $t-5$ and $t$ and $t=1935,1940 . P L A N 1_{i}$ and $P L A N 2_{i}$ are indicator variables for whether a village was selected for planning in period 1 (1930-1934) or in period 2 (1935-1939), respectively, as depicted in Figure 2. $S S P_{i}$ is a similar indicator variable for selection to SSP in period 2, and

16 The denominator is the number of farm households. However, for 1940, only the "number of rice-farming farm households" instead of "number of farm households" was reported. Thus, strictly speaking, the definition of the outcome with respect to the adoption of animal husbandry is not consistent across the three time periods examined. Alternatively, the number of households could be used as the denominator. The main results us ing this alternative outcome are mostly similar (results available on request).

17 Many plans in fact specified cattle, cocoons, and chickens as the target livestock; horses were rarely mentioned. Unfortunately, the data for cocoons and chickens are not available throughout the three time points. 
$Y 1935$ and $Y 1940$ are year dummies. $\Delta X_{i}$ is a vector of the change of time-variant village characteristics, namely, the number of households and farm households. ${ }^{18}$

Under this specification, $\beta$ s measures the change of outcomes over time for treated villages, in the period after the selection, relative to the change in outcomes for villages that had never been selected, either for planning or for receiving a special subsidy (i.e., non-PLAN2 in Figure 2). For example, $\beta_{1}$ is the difference in the change of outcomes from 1930 to 1935 between villages selected for planning in period 1 (PLAN1) and those that had never been selected for the ERM (non-PLAN2). The coefficient of the interaction term $P L A N 1_{i} \times S S P_{i}$ $\left(\gamma_{1}\right)$ is the additional effect of SSP for PLAN1 villages in period 2. This specification also measures pre-treatment trends with $\delta$ s. For example $\delta_{2}$ is the difference in the trends in period 1 (pre-treatment trends) between PLAN2 villages and the never-treated.

Panel A in Table 3 reports the results. Some coefficients are missing owing to a lack of outcome data for 1940. Selection for planning in period 1 (PLAN1) had a significant effect on the adoption of raising cattle and pigs in period $1^{19}$. During period 1 , the increase in the percentage of farm households raising cattle in PLAN1 villages was 3.13 percentage points more than that in never-treated villages; this accounted for a $5.7 \%$ increase $^{20}$ for PLAN1 villages from 1930 to 1935 . This effect, however, seemed to disappear in period 1 ; the effect is positive but not statistically significant for period 2. Moreover, in period 2, the percentage of farm households raising pigs in PLAN1 villages significantly declined. PLAN2 villages experienced a similar pattern during period 2; these villages adopted more cattle raising (i.e., a 3.51 percentage-point increase or $6.5 \%$ increase in the ratio of farm households raising cattle), but the effect on the introduction of pig raising is negative. In addition to the effect on cattle raising, the coefficient of PLAN2*1940 for the diversification index is positive and significant (a 2.8\% increase during 1935 to 1940), implying a successful diversification of production.

The interaction term of PLAN1*SSP*1940 measures the additional effect of being

\footnotetext{
${ }^{18}$ Unfortunately, other variables, such as the composition of farm households in terms of full-time vs. part-time, tenancy status, or farm size, are not available for 1940.

${ }^{19}$ Four villages are dropped from the estimation for the results regarding the adoption of animal husbandry either because the denominator (i.e., the number of rice-farming farm households) showed an abnormal trend or it is zero in 1940.

20 The mean pre-treatment value of the percentage of households raising cattle for PLAN1 villages in 1930 is $54.7 \%$. Therefore, a 3.13 percentage-point increase accounts for a 3.13/54.5 $=5.7 \%$ increase.
} 
selected for SSP in period 2, on top of the effect of the selection for planning in period 1. However, I do not find any statistically significant difference. I also find no effect on the adoption of horse raising and on the percentage of part-time farmers for any of the interaction terms (columns (4) and (5)). This could be because horse raising was not as popular in Hyogo and the increase of part-time farmers depended primarily on the distance to urban cities. The result in column (3) indicates that although some of the coefficients had are not precisely estimated, pig farming tended to decline in period 2. This seems to reflect the fact that the use of fodder was prioritized for feeding cows and horses following the outbreak of the Sino-Japanese War in 1937 (Ministry of Agriculture, Forestry, and Fisheries, 1980).

The interaction terms in italics (PLAN1*SSP*1935 and PLAN2*1935) measure the pre-treatment trends. I find that in terms of the diversification index, PLAN1 villages selected for SSP had performed better, even before selection (i.e., in period 1), than PLAN1 villages that had not been selected for SSP in period 2. Similarly, PLAN2 villages had already made more progress in terms of raising cattle and pigs than the never-treated villages, even before selection. These findings may imply that the selection for SSP or planning in period 2 was conditional on performance in period 1 . On the other hand, it also raises concerns regarding selection bias, which is discussed next.

\subsection{Robustness}

Here, I discuss two concerns that may have biased the estimates in Table 3. First, in section 3.2, I have discovered that the treated villages were more agriculturally oriented than the non-treated ones. Note that if we take the first difference, the time-invariant component of unobservable village characteristics is differenced out of the regression on the level of outcome, but the influence on the trend of outcome may still remain. This raises the concern that the change of outcomes might have been greater for agriculturally oriented villages, for example, because such villages have fewer choices over whether to intensify their agricultural practices. Although it is not possible to address these issues completely, I include one-period lagged values of key village characteristics in order to consider this concern. ${ }^{21}$ The results thereof are reported in Table 4 . The results are similar, except that the positive coefficient of PLAN2*1935

${ }^{21}$ The controlled village characteristics are number of farm households, percentage of farm households to all households, percentages of full-time farmers, percentages of farm households by tenancy status, and percentages of farm households by farm-size class. 
for the adoption of cattle raising lost its statistical significance.

The second concern is raised in Table 3, where the pre-treatment trend for the adoption of cattle was greater for PLAN2 than for non-PLAN2. This suggests that the coefficient of PLAN2*1940 for this outcome may have been overestimated because the change in period 2 might have also been greater than the never-treated villages, even in the absence of treatment. (This concern is not true for the coefficient of PLAN2*1940 for the diversification index.) To address this concern, I follow the strategy proposed by Feder, Murgai, and Quizon (2003) in order to examine whether changes in outcomes during the period after selection were greater than changes in outcomes during the period prior to selection. That is, I perform the one-sided tests $\beta_{3}>\delta_{2}$ (i.e., the coefficient of PLAN2*1940 is larger than the coefficient of PLAN2*1935) and $\gamma_{1}>\delta_{1}$ (i.e., the coefficient of PLAN1*SSP*1940 is larger than the coefficient of PLAN1*SSP*1935) against the null hypothesis that no difference exists between pre- and post-treatment trends. Panel B of Tables 3 and 4 indicate that although the trends pertaining to the diversification index and percentage of farm households raising cattle for period 2 are both greater than those for period 1 in PLAN2, we cannot reject the null hypothesis that the trends are equal. This, however, seems to be affected by common shocks that might have slowed down the trend in period 2. First, the outbreak of World War II in 1937 increased controls and restrictions on agricultural production and economic activities. Second, inflation during period 2 increased agricultural incomes and reduced debt.

Another related test is to include a village fixed effect in equation (1), in order to use the change of trend in period 2 relative to the trend in period 1 within each village. Table 5 provides the results. Since it is unlikely that trends vary during a short period of time, it is not surprising that many of the coefficients are not precisely estimated. The coefficients of the year 1940 dummy measure the change of trends for the reference group, that is, never-treated villages. The coefficients indicate that the trend in period 2 was no different from that in period 1, except for the percentage of farm households raising cattle. The coefficients of the interaction terms measure the differences in the changes in trends, relative to the never-treated villages. Once again, although the coefficients of PLAN2*1940 for the diversification index and adoption of cattle are positive, none of the interaction terms are significantly positive; this is consistent with the hypothesis test in Panel B of Table 3. Thus, I cannot claim that the ERM accelerated the trends under examination; (the deceleration in the adoption of pig farming seems to reflect the 
effect of war, as indicated above).

Overall, the results suggest that the villages that had been selected for planning experienced a greater change in terms of the adoption of cattle raising and crop diversification, in comparison to never-treated villages, during the post-selection period. However, the possibility that the effects of ERM are overestimated due to selection bias cannot be completely ruled out. It is known that the ERM was inspired by the pioneering "Self-Rehabilitation Movement” (Jiriki kosei undo) in Hyogo prefecture, which started in 1927. Shoji (1991) indicates that many of the villages that were ultimately selected for the ERM had already been selected for this Movement and conducted their own rural planning. Therefore, the results may have picked up the effects of this forerunning program.

\section{Concluding remarks}

This paper studies the characteristics and economic effects of a rural development program in Japan during the 1930s. The program, called the rural ERM, was probably the earliest nationwide participatory development program; it had features similar to those of today's community-driven development interventions. This paper represents the first quantitative examination of the determinants of program participation and its effect on economic outcomes.

I find that relatively agriculturally oriented villages were more likely to participate in the program. Through the best use of the available historical data, I find suggestive evidence that households in the villages that had been selected for the program had improved their financial standings by reducing their debt. Moreover, the selected villages tended to adopt cattle raising and diversify agricultural production more actively than non-treated villages during the period following the establishment of their respective rehabilitation plans. These were the most feasible strategies for improving income, primarily by utilizing idle labor in the slack season. However, given that, for some subgroups, the pre-treatment trend was greater even before the treatment, the possibility that some of the results are overestimated could not be ruled out; this was likely due to the contaminating effects of a similar program that had been implemented prior to the ERM. Further rigorous study is required to establish a causal link between the ERM and the outcomes.

This paper also discusses a number of interesting features that may be useful in the 
current implementation of rural development programs. For example, conducting a baseline survey through the hands of the villagers themselves seems to be effective in helping them to become more conscious of the problems that they face and allows them to be able to see the issues at hand with greater clarity. It is also interesting that many villages embraced an incentive scheme to promote the implementation of the established plan through tournament-like competition among communities. Contrary to the criticisms that a lack of budgetary support until the start of SSP may have prevented the movement from making any real impact, these features might have actually been effective in making real changes.

We should bear in mind that the ERM program and the rehabilitation plans were multi-dimensional. Different villages might have had goals and strategies different from those this paper examines. For example, I find that SSP had no impact on crop diversification or the adoption of livestock-raising; however, subsidies had mostly been invested into infrastructure and land improvement, for which effects were likely to be realized only in the long run. Studying the impact of the program on other outcomes and on long-run consequences remains a subject for future study.

\section{Acknowledgements}

I extend my heartfelt gratitude to Yohei Kojima for his excellent assistance in collecting data and creating the dataset. I also extend my gratitude to Naohito Abe, Kunio Ohkama, Chiaki Moriguchi, Yoshihiro Sakane, Osamu Saito, and the participants of the $78^{\text {th }}$ Conference of the Socio Economic History Association (Toyo University) and the seminar at Kyoto University for their valuable comments and advice. I gratefully acknowledge the support provided by a grant-in-aid from the Fellows of the Japan Society for the Promotion of Science (JSPS) and the Ministry of Education, Culture, Sports, Science, and Technology of the Japanese government (KAKENHI-06J10041). Any errors found herein are my own.

\section{References}

Binswanger-Mkhize, Hans P.; Jacomina P. de Regt; and Stephen Spector, eds. 2010. Local and Community Driven Development. Washington, DC: World Bank.

Feder, Gershon; Rinku Murgai; and Jaime B. Quizon. 2003. "Sending Farmers Back to School: The Impact of Farmer Field Schools in Indonesia.” Review of Agricultural Economics 26, no. 
1: 45-62.

Godo, Yoshihisa. 1995. "Noson keizai kosei tokubetsu josei seido no seisaku hyoka (Economic Aspects of Noson Keizaikosei Tokubetsu Josei Seido (Special Subsidy Program for Rural Economic Recovery)).” Nogyo mondai kenkyu 31, no. 1: 33-40. (in Japanese)

Hatta, Sadao. 1996. "Showa shoki ni okeru nosan-gyoson keizai kosei undo no tenkai (Movement for Rural Reconstruction in the 1930s: Japan’s Experience in Restoring Damage Caused by the Great Depression).” Kaihatsu-gaku kenkyu 7, no. 1: 73-82. (in Japanese)

Hiraga, Akihiko. 2003. Senzen nihon nogyo seisaku-shi no kenkyu: 1920-1945 (A Study on the History of Agricultural Policy in Prewar Japan: 1920-1945). Tokyo: Nihon keizai hyoron sha. (in Japanese)

Hyogo Prefecture. 1937a. Keizai kosei keikaku jikkojirei (Cases of Implementation of Economic Rehabilitation Plan), vol. 1. (in Japanese)

Hyogo Prefecture. 1937b. Keizai kosei keikaku jikkojirei (Cases of Implementation of Economic Rehabilitation Plan), vol. 2. (in Japanese)

Hyogo Prefecture. 1938. Nosan-gyoson keizai kosei no zenbo (The Entire Picture of Rural Economic Rehabilitation). (in Japanese)

Inoue, Harumaru. 1957. "Nogyo kyoko kara senso keizai-ka no nogyo he (From Depression to Agriculture under a Wartime Economy).” In Nihon nogyo hattatsu-shi (History of Japanese Agricultural Development), vol. 8, ed. Nogyo-hattatsu-shi-chosa-kai. Tokyo: Chuo-koron-sha. (in Japanese)

Jack, William. 2001. "Social Investment Funds: An Organizational Approach to Improved Development Assistance.” World Bank Research Observer 16, no. 1: 109-124.

Kamiya, Keiji. 1937. “Keizai kosei keikaku juritsu-son ha hi-kosei-son ni hishite jinko wo zouka seshimeshi ya ina-ya (Did Populations Grow Faster in Villages Selected for Establishing the Economic Rehabilitation Plan, Than in Non-selected?).” Nogyo keizai kenkyu 13, no. 2: 127-137. (in Japanese)

Kodaira, Gonichi. 1932. "Noson-taisaku no kicho (The Basic Direction of Rural Relief)." Shimin 27, no. 8:1-3. (in Japanese)

Mansuri, Ghazala, and Vijayendra Rao. 2004. “Community-Based and -Driven Development: A Critical Review.” World Bank Research Observer 19, no. 1: 1-39.

Ministry of Agriculture and Forestry. 1933, 1935. Keizai kosei keikaku jikko jokyo chosa 
(Research on the Progress of the Economic Rehabilitation Plan), vols. 1-3. (in Japanese)

Ministry of Agriculture and Forestry. 1936. Zenkoku yuryo kosei noson keizai kosei keikaku oyobi sono jikko jokyo (The Economic Rehabilitation Plan and Its Progress in the Best-performing Villages). (in Japanese)

Ministry of Agriculture and Forestry. 1938. Nosan-gyoson keizai kosei keikaku no gaiyo oyobi sono jisseki (Outline of the Rural Economic Rehabilitation Plan and Its Achievement). (in Japanese)

Ministry of Agriculture, Forestry, and Fisheries. 1980. Norin-suisan-sho hyaku-nen-shi (One Hundred years of the Ministry of Agriculture, Forestry and Fisheries), vol. 2. Tokyo: Norin Tokei Kyokai. (in Japanese)

Mori, Yoshizo. 1998. Showa-shoki no keizai kosei undo to noson keikaku (The Economic Rehabilitation Movement and Rural Planning in the Early Showa Period). Sendai: Tohoku University Press. (in Japanese)

Okada, Tomohiro. 1989. Nihon shihon-shugi to noson kaihatsu (Japanese Capitalism and Rural Development). Kyoto: Horitsu-bunka-sha. (in Japanese)

Rawlings, Laura; Lynne Sherburne-Benz; and Julie Van Domelen. 2004. Evaluating Social Fund Performance: A Cross-country Analysis of Community Investments. Washington, DC: World Bank.

Shoji, Shunsaku. 1991. Kindai nihon noson-shakai no tenkai (The Development of Rural Society in Modern Japan). Tokyo: Minerva Shobo. (in Japanese)

Takahashi, Yasutaka. 1997. Showa senzen-ki no noson to Manshu-imin (Agricultural Community in Prewar-Showa Period and Manchurian Migration). Tokyo: Yoshikawa-kobun-kan. (in Japanese)

World Bank. 2005. The Effectiveness of World Bank Support for Community-Based and -Driven Development: An OED Evaluation. Washington, DC: World Bank.

World Bank. 2007. World Development Report 2008: Agriculture for Development. Washington, DC: World Bank.

Yasutomi, Kunio. 1994. Showa kyoko-ki kyu-no seisaku-shi-ron (Historical Study of Rural Relief Policy in the Showa Depression Period). Tokyo: Hassaku-sha. (in Japanese) 
Table 1. Pre-treatment values of village characteristics

\begin{tabular}{|c|c|c|c|c|c|c|c|c|c|c|c|c|}
\hline & \multicolumn{4}{|c|}{$\begin{array}{c}\text { Panel } A . \\
\text { PLAN1 vs. non-PLAN1: Pre-treatment values in } 1930 \\
\end{array}$} & \multicolumn{4}{|c|}{$\begin{array}{c}\text { Panel } B . \\
\text { PLAN2 vs. non-PLAN2: Pre-treatment values in } 1935\end{array}$} & \multicolumn{4}{|c|}{$\begin{array}{c}\text { Panel C. } \\
\text { SSP vs. non-SSP: Pre-treatment values in } 1935\end{array}$} \\
\hline & \multirow{2}{*}{$\begin{array}{c}\text { non-PLAN1 } \\
\text { Mean }\end{array}$} & \multirow{2}{*}{$\begin{array}{c}\text { PLAN1 } \\
\text { Mean }\end{array}$} & \multicolumn{2}{|c|}{ Difference } & \multirow{2}{*}{$\begin{array}{c}\text { non-PLAN2 } \\
\text { Mean }\end{array}$} & \multirow{2}{*}{$\begin{array}{l}\text { PLAN2 } \\
\text { Mean }\end{array}$} & \multicolumn{2}{|c|}{ Difference } & \multirow{2}{*}{$\begin{array}{c}\text { non-SSP } \\
\text { Mean }\end{array}$} & \multirow{2}{*}{$\begin{array}{l}\text { SSP } \\
\text { Mean }\end{array}$} & \multicolumn{2}{|c|}{ Difference } \\
\hline & & & Mean & S.E. & & & Mean & S.E. & & & Mean & S.E. \\
\hline & $(1)$ & $(2)$ & (3) & (4) & $(5)$ & $(6)$ & (7) & (8) & (9) & $(10)$ & $(11)$ & $(12)$ \\
\hline Population & 3990.12 & 3015.26 & $-974.9 * * *$ & (250.9) & 5167.00 & 3193.11 & $-1,974 * * *$ & (612.4) & 3198.59 & 2612.77 & $-585.8^{* *}$ & (269.9) \\
\hline Number of households & 815.10 & 606.88 & $-208.2^{* * *}$ & (51.61) & 1063.36 & 643.47 & $-419.9 * * *$ & (123.9) & 645.16 & 532.65 & $-112.5^{* *}$ & (53.30) \\
\hline Number of farm households & 454.22 & 468.87 & 14.65 & $(24.42)$ & 437.27 & 456.29 & 19.02 & (30.69) & 474.91 & 418.62 & -56.30 & $(35.63)$ \\
\hline Farm household (\%) & 66.62 & 79.15 & $12.54 * * *$ & (2.389) & 55.65 & 75.65 & $20.00 * * *$ & (3.182) & 76.93 & 79.76 & 2.833 & $(2.812)$ \\
\hline Full-time farmers (\%) & 61.76 & 66.85 & $5.089 *$ & $(2.875)$ & 60.15 & 64.03 & 3.882 & $(2.713)$ & 68.13 & 67.50 & -0.634 & $(4.864)$ \\
\hline Part-time farmers (\%) & 38.24 & 33.15 & $-5.089 *$ & $(2.875)$ & 39.85 & 35.97 & -3.882 & $(2.713)$ & 31.87 & 32.50 & 0.634 & $(4.864)$ \\
\hline Owner-cultivator (\%) & 26.88 & 28.03 & 1.152 & (1.775) & 24.62 & 29.42 & $4.797^{* * *}$ & (1.538) & 28.28 & 26.05 & -2.231 & (2.147) \\
\hline Owner-cum -tenant (\%) & 42.52 & 45.59 & $3.076^{*}$ & (1.775) & 41.46 & 45.29 & 3.828 & (2.241) & 44.07 & 47.39 & 3.325 & (2.746) \\
\hline Tenant farmers (\%) & 30.60 & 26.37 & $-4.227^{* * *}$ & (1.202) & 33.92 & 25.30 & $-8.624 * * *$ & $(2.266)$ & 27.65 & 26.56 & -1.094 & (2.674) \\
\hline Farm size class: $<0.5$ cho (\%) & 44.72 & 38.91 & $-5.811 * *$ & (2.239) & 44.03 & 44.25 & 0.217 & (3.016) & 37.32 & 39.47 & 2.154 & (3.459) \\
\hline Farm size class: $0.5-1$ cho (\%) & 41.05 & 45.02 & $3.970^{* *}$ & (1.848) & 40.88 & 41.13 & 0.247 & $(2.132)$ & 43.46 & 42.15 & -1.315 & (2.921) \\
\hline Farm size class: $1-2$ cho (\%) & 13.31 & 15.11 & 1.808 & (1.861) & 14.21 & 13.57 & -0.642 & (1.861) & 18.24 & 16.44 & -1.795 & (2.606) \\
\hline Farm size class: >2 cho (\%) & 0.94 & 0.99 & 0.0544 & $(0.258)$ & 0.87 & 1.05 & 0.176 & $(0.226)$ & 0.98 & 1.94 & 0.957 & (0.903) \\
\hline Diversification index & 0.55 & 0.54 & -0.0164 & $(0.0156)$ & 0.56 & 0.56 & -0.00130 & $(0.0129)$ & 0.56 & 0.53 & -0.0255 & $(0.0184)$ \\
\hline Farm households raising cattle (\%) & 47.59 & 54.48 & $6.893^{* * *}$ & (2.004) & 44.98 & 53.91 & $8.926^{* *}$ & (3.330) & 57.59 & 61.96 & 4.374 & (4.409) \\
\hline Farm households raising pigs (\%) & 0.62 & 0.84 & 0.219 & (0.214) & 1.82 & 2.48 & $0.658^{*}$ & $(0.371)$ & 3.83 & 4.02 & 0.190 & (0.911) \\
\hline Farm households raising horses (\%) & 4.35 & 2.95 & $-1.398^{* *}$ & $(0.602)$ & 4.11 & 3.12 & -0.983 & $(0.877)$ & 2.92 & 2.10 & -0.822 & $(0.797)$ \\
\hline
\end{tabular}

Notes: See Figure 2 for definitions of PLAN1, PLAN2, and SSP. "Farm size class" is the percentage of farm households in the indicated farm size class. One cho is approximately 1 ha. Robust standard errors, indicated in parentheses, are clustered by county. ${ }^{* *} \mathrm{p}<0.01,{ }^{* *} \mathrm{p}<0.05,{ }^{*} \mathrm{p}<0.1$. 
Table 2. Determinants of selection (probit estimates, marginal effects)

\begin{tabular}{|c|c|c|c|}
\hline & & Selection for: & \\
\hline & $\begin{array}{l}\text { PLAN1 } \\
(1) \\
\end{array}$ & $\begin{array}{c}\text { PLAN2 } \\
(2) \\
\end{array}$ & $\begin{array}{r}\text { SSP } \\
(3)\end{array}$ \\
\hline Number of farm households & $\begin{array}{l}-3.35 e-05 \\
(0.000100)\end{array}$ & $\begin{array}{l}-0.000120 \\
(0.000142)\end{array}$ & $\begin{array}{l}-0.000591 \\
(0.000458)\end{array}$ \\
\hline Farm households (\%) & $\begin{array}{l}0.00458^{* * *} \\
(0.00114)\end{array}$ & $\begin{array}{l}0.00945^{* * *} \\
(0.00158)\end{array}$ & $\begin{array}{l}0.00382 \\
(0.00366)\end{array}$ \\
\hline Full-time farmers (\%) & $\begin{array}{l}-0.000155 \\
(0.00114)\end{array}$ & $\begin{array}{l}-0.000991 \\
(0.00222)\end{array}$ & $\begin{array}{l}-0.00245 \\
(0.00328)\end{array}$ \\
\hline Owner-cultivator (\%) & $\begin{array}{l}0.000527 \\
(0.00189)\end{array}$ & $\begin{array}{l}0.00533 \\
(0.00334)\end{array}$ & $\begin{array}{l}-0.00465 \\
(0.00544)\end{array}$ \\
\hline Owner-cum-tenant (\%) & $\begin{array}{l}0.00145 \\
(0.00157)\end{array}$ & $\begin{array}{l}0.00440 \\
(0.00343)\end{array}$ & $\begin{array}{l}0.000801 \\
(0.00503)\end{array}$ \\
\hline Farm size class: $0.5-1$ cho (\%) & $\begin{array}{l}0.00149 \\
(0.00160)\end{array}$ & $\begin{array}{l}-0.00425 \\
(0.00355)\end{array}$ & $\begin{array}{l}-0.00181 \\
(0.00673)\end{array}$ \\
\hline Farm size class: $1-2$ cho (\%) & $\begin{array}{l}-3.53 e-05 \\
(0.00193)\end{array}$ & $\begin{array}{l}-0.00867^{* *} \\
(0.00433)\end{array}$ & $\begin{array}{l}-0.0112^{* *} \\
(0.00452)\end{array}$ \\
\hline Farm size class: >2 cho (\%) & $\begin{array}{l}0.00138 \\
(0.00744)\end{array}$ & $\begin{array}{l}0.0252^{*} \\
(0.0150)\end{array}$ & $\begin{array}{l}0.0339 * \\
(0.0205)\end{array}$ \\
\hline Diversification index & $\begin{array}{l}-0.0797 \\
(0.257)\end{array}$ & $\begin{array}{l}-0.244 \\
(0.332)\end{array}$ & $\begin{array}{l}-0.702 \\
(0.733)\end{array}$ \\
\hline Farm households raising cattle (\%) & $\begin{array}{l}0.00136 \\
(0.000927)\end{array}$ & $\begin{array}{l}0.00363 \\
(0.00241)\end{array}$ & $\begin{array}{l}0.00485 \\
(0.00348)\end{array}$ \\
\hline Farm households raising pigs (\%) & $\begin{array}{l}0.0198^{*} \\
(0.0103)\end{array}$ & $\begin{array}{l}0.0158^{*} \\
(0.00816)\end{array}$ & $\begin{array}{l}0.00394 \\
(0.00728)\end{array}$ \\
\hline Farm households raising horses (\%) & $\begin{array}{l}-0.00545^{*} \\
(0.00287)\end{array}$ & $\begin{array}{l}0.00484 \\
(0.00539)\end{array}$ & $\begin{array}{l}-0.0163 \\
(0.0225)\end{array}$ \\
\hline Population & $\begin{array}{c}\text { All } \\
\text { municipalities }\end{array}$ & non-PLAN1 & PLAN1 \\
\hline Observations & 385 & 301 & 84 \\
\hline Pseudo R2 & 0.0819 & 0.178 & 0.130 \\
\hline Log likelihood & -185.4 & -171.3 & -45.23 \\
\hline
\end{tabular}

Notes: Marginal effects reported. The dependent variables are indicator variables of selection. See Figure 2 for definitions of PLAN1, PLAN2, and SSP. Independent variables are pre-treatment values in 1930 for column (1) and 1935 for columns (2) and (3). One cho is approximately 1 ha. The reference categories are part-time farmers (\%) for full-time farmers (\%); tenant farmers (\%) for owner-cultivators (\%) and owner-cum-tenants (\%); and farm size class $<0.5$ cho for farm size class. Robust standard errors, indicated in parentheses, are clustered at the county level. ${ }^{* * *} \mathrm{p}<0.01,{ }^{* *} \mathrm{p}<0.05,{ }^{*} \mathrm{p}<0.1$. 
Table 3. Effect of the Economic Rehabilitation Movement (ERM)

\begin{tabular}{|c|c|c|c|c|c|}
\hline & $\begin{array}{c}\text { Diversifi- } \\
\text { cation index }\end{array}$ & $\begin{array}{c}\text { Farm } \\
\text { households } \\
\text { raising } \\
\text { cattle }(\%) \\
\end{array}$ & $\begin{array}{c}\text { Farm } \\
\text { households } \\
\text { raising pigs } \\
(\%)\end{array}$ & $\begin{array}{c}\text { Farm } \\
\text { households } \\
\text { raising } \\
\text { horses (\%) } \\
\end{array}$ & $\begin{array}{c}\text { Part-time } \\
\text { farmers (\%) }\end{array}$ \\
\hline & (1) & (2) & (3) & (4) & (5) \\
\hline \multicolumn{6}{|l|}{ Panel A. Parameters } \\
\hline PLAN1*1935 & $\begin{array}{l}-0.00783 \\
(0.0107)\end{array}$ & $\begin{array}{l}3.125^{* * *} \\
(1.105)\end{array}$ & $\begin{array}{l}1.958^{* * *} \\
(0.472)\end{array}$ & $\begin{array}{l}0.642 \\
(0.487)\end{array}$ & $\begin{array}{l}-0.0630 \\
(2.862)\end{array}$ \\
\hline PLAN1*1940 & $\begin{array}{l}0.00764 \\
(0.0107)\end{array}$ & $\begin{array}{l}1.015 \\
(1.270)\end{array}$ & $\begin{array}{l}-1.894^{* *} \\
(0.688)\end{array}$ & & \\
\hline PLAN2*1940 & $\begin{array}{l}0.0155^{* *} \\
(0.00669)\end{array}$ & $\begin{array}{l}3.508^{* * *} \\
(0.955)\end{array}$ & $\begin{array}{l}-0.969 * \\
(0.504)\end{array}$ & & \\
\hline PLAN1*SSP*1940 & $\begin{array}{l}0.0133 \\
(0.00962)\end{array}$ & $\begin{array}{l}-1.924 \\
(1.657)\end{array}$ & $\begin{array}{l}-0.255 \\
(0.647)\end{array}$ & & \\
\hline PLAN1*SSP*1935 & $\begin{array}{l}0.0317^{* * *} \\
(0.0108)\end{array}$ & $\begin{array}{l}0.522 \\
(2.318)\end{array}$ & $\begin{array}{l}-0.240 \\
(0.801)\end{array}$ & $\begin{array}{l}-0.250 \\
(0.468)\end{array}$ & $\begin{array}{l}-2.533 \\
(4.544)\end{array}$ \\
\hline PLAN2*1935 & $\begin{array}{l}-0.000175 \\
(0.00900)\end{array}$ & $\begin{array}{l}2.266 * * \\
(0.924)\end{array}$ & $\begin{array}{l}0.788 * * \\
(0.354)\end{array}$ & $\begin{array}{l}0.0950 \\
(0.285)\end{array}$ & $\begin{array}{l}-0.823 \\
(1.376)\end{array}$ \\
\hline Year $=1940$ & $\begin{array}{l}0.00517 \\
(0.0125)\end{array}$ & $\begin{array}{l}3.137^{*} \\
(1.833)\end{array}$ & $\begin{array}{l}-0.829 \\
(0.595)\end{array}$ & & \\
\hline Constant & $\begin{array}{l}0.00987 \\
(0.00803)\end{array}$ & $\begin{array}{l}0.596 \\
(0.751)\end{array}$ & $\begin{array}{l}1.142^{* * *} \\
(0.298)\end{array}$ & $\begin{array}{l}-0.962^{* *} \\
(0.423)\end{array}$ & $\begin{array}{l}0.269 \\
(1.237)\end{array}$ \\
\hline N & 769 & 766 & 766 & 385 & 385 \\
\hline$R 2$ & 0.029 & 0.207 & 0.116 & 0.043 & 0.017 \\
\hline Panel B. Hypothesis test ( $p$-values) & & & & & \\
\hline PLAN2*1940>PLAN2*1935 & 0.132 & 0.216 & 0.984 & & \\
\hline PLAN1*SSP*1940>PLAN1*SSP*1935 & 0.860 & 0.748 & 0.505 & & \\
\hline
\end{tabular}

Notes: The dependent variables are the changes in indicated outcomes. See Figure 2 for definitions of PLAN1, PLAN2, and SSP. Interaction terms, indicated in italics, measure pre-treatment trends. All regressions include changes in village characteristics (number of households and number of farm households). Robust standard errors, in parentheses, are clustered by county. ${ }^{* * *} \mathrm{p}<0.01$, ${ }^{* *} \mathrm{p}<0.05$, ${ }^{*} \mathrm{p}<0.1$. The hypothesis test in Panel B tests the null hypothes is that there is no difference between pre- and post-treatment trends. 
Table 4. Robustness: Controlling for lagged values of village characteristics

\begin{tabular}{|c|c|c|c|c|c|}
\hline & $\begin{array}{l}\text { Diversifi- } \\
\text { cation index }\end{array}$ & $\begin{array}{c}\text { Farm } \\
\text { households } \\
\text { raising } \\
\text { cattle }(\%) \\
\end{array}$ & $\begin{array}{c}\text { Farm } \\
\text { households } \\
\text { raising pigs } \\
(\%) \\
\end{array}$ & $\begin{array}{c}\text { Farm } \\
\text { households } \\
\text { raising } \\
\text { horses (\%) }\end{array}$ & $\begin{array}{c}\text { Part-time } \\
\text { farmers (\%) }\end{array}$ \\
\hline & $(1)$ & $(2)$ & (3) & (4) & (5) \\
\hline \multicolumn{6}{|l|}{ Panel A. Parameters } \\
\hline PLAN1*1935 & $\begin{array}{l}-0.00864 \\
(0.0103)\end{array}$ & $\begin{array}{l}2.933^{* *} \\
(1.124)\end{array}$ & $\begin{array}{l}2.205^{* * *} \\
(0.540)\end{array}$ & $\begin{array}{l}0.164 \\
(0.374)\end{array}$ & $\begin{array}{l}0.0376 \\
(2.215)\end{array}$ \\
\hline PLAN1*1940 & $\begin{array}{l}0.00756 \\
(0.0113)\end{array}$ & $\begin{array}{l}0.00797 \\
(1.404)\end{array}$ & $\begin{array}{l}-1.726^{* * *} \\
(0.555)\end{array}$ & & \\
\hline PLAN2*1940 & $\begin{array}{l}0.0165^{* *} \\
(0.00671)\end{array}$ & $\begin{array}{l}2.875^{* *} \\
(1.133)\end{array}$ & $\begin{array}{l}-0.655^{*} \\
(0.332)\end{array}$ & & \\
\hline PLAN1*SSP*1940 & $\begin{array}{l}0.0127 \\
(0.00941)\end{array}$ & $\begin{array}{l}-2.761 \\
(1.841)\end{array}$ & $\begin{array}{l}-0.0928 \\
(0.652)\end{array}$ & & \\
\hline PLAN1*SSP*1935 & $\begin{array}{l}0.0305^{* * *} \\
(0.0108)\end{array}$ & $\begin{array}{l}-0.333 \\
(2.473)\end{array}$ & $\begin{array}{l}-0.244 \\
(0.764)\end{array}$ & $\begin{array}{l}-0.275 \\
(0.465)\end{array}$ & $\begin{array}{l}-0.476 \\
(3.927)\end{array}$ \\
\hline PLAN2*1935 & $\begin{array}{l}6.94 e-05 \\
(0.00863)\end{array}$ & $\begin{array}{l}1.479 \\
(1.114)\end{array}$ & $\begin{array}{l}1.055^{* *} \\
(0.480)\end{array}$ & $\begin{array}{l}-0.420 * \\
(0.223)\end{array}$ & $\begin{array}{l}0.469 \\
(1.568)\end{array}$ \\
\hline Year $=1940$ & $\begin{array}{l}0.00277 \\
(0.0126)\end{array}$ & $\begin{array}{l}4.479 * * \\
(1.766)\end{array}$ & $\begin{array}{l}-0.849 \\
(0.543)\end{array}$ & & \\
\hline Constant & $\begin{array}{l}-0.00967 \\
(0.0218)\end{array}$ & $\begin{array}{l}-2.067 \\
(2.978)\end{array}$ & $\begin{array}{l}1.699 * * \\
(0.767)\end{array}$ & $\begin{array}{l}-1.965 \\
(1.872)\end{array}$ & $\begin{array}{l}-10.73^{*} \\
(5.271)\end{array}$ \\
\hline$N$ & 770 & 766 & 766 & 385 & 385 \\
\hline$R 2$ & 0.046 & 0.110 & 0.126 & 0.050 & 0.236 \\
\hline Panel B. Hypothesis test ( $p$-values) & & & & & \\
\hline PLAN2*1940>PLAN2*1935 & 0.123 & 0.221 & 0.984 & & \\
\hline PLAN1*SSP*1940>PLAN1*SSP*1935 & 0.851 & 0.729 & 0.454 & & \\
\hline
\end{tabular}

Notes: The dependent variables are the changes in indicated outcomes. See Figure 2 for definitions of PLAN1, PLAN2, and SSP. See the main text for controlled village characteristics. Robust standard errors, indicated in parentheses, are clustered by county. ${ }^{* * *} \mathrm{p}<0.01,{ }^{* *} \mathrm{p}<0.05,{ }^{*} \mathrm{p}<0.1$. The hypothesis test in Panel B tests the null hypothesis that there is no difference between pre- and post-treatment trends. 
Table 5. First-difference estimates with village fixed effects

\begin{tabular}{|c|c|c|c|}
\hline & $\begin{array}{l}\text { Diversifi- } \\
\text { cation index }\end{array}$ & $\begin{array}{c}\text { Farm } \\
\text { households } \\
\text { raising } \\
\text { cattle (\%) }\end{array}$ & $\begin{array}{c}\text { Farm } \\
\text { households } \\
\text { raising pigs } \\
(\%) \\
\end{array}$ \\
\hline & (1) & (2) & (3) \\
\hline \multirow[t]{2}{*}{ PLAN1*1940 } & 0.0174 & -3.040 & $-3.852^{* * *}$ \\
\hline & $(0.0196)$ & (2.146) & $(0.995)$ \\
\hline \multirow[t]{2}{*}{ PLAN2*1940 } & 0.0168 & 1.652 & $-1.715^{* *}$ \\
\hline & $(0.0132)$ & (1.864) & $(0.747)$ \\
\hline \multirow[t]{2}{*}{ PLAN1*SSP*1940 } & -0.0187 & -1.908 & 0.00132 \\
\hline & $(0.0167)$ & (4.079) & (1.339) \\
\hline \multirow[t]{2}{*}{ Year $=1940$} & 0.00331 & $4.129 * *$ & -0.827 \\
\hline & $(0.0121)$ & $(1.841)$ & $(0.555)$ \\
\hline \multirow[t]{2}{*}{ Constant } & $0.00950^{* * *}$ & $2.318^{* * *}$ & $1.853^{* * *}$ \\
\hline & $(0.00280)$ & $(0.521)$ & $(0.303)$ \\
\hline$N$ & 770 & 766 & 766 \\
\hline$R 2$ & 0.018 & 0.065 & 0.139 \\
\hline
\end{tabular}

Notes: The dependent variables are the changes in indicated outcomes. See Figure 2 for definitions of PLAN1, PLAN2, and SSP. All regressions include village fixed effects. Robust standard errors, in parentheses, are clustered by county. ${ }^{* * *} \mathrm{p}<0.01,{ }^{* *} \mathrm{p}<0.05,{ }^{*} \mathrm{p}<0.1$. 
Figures

(Selection)

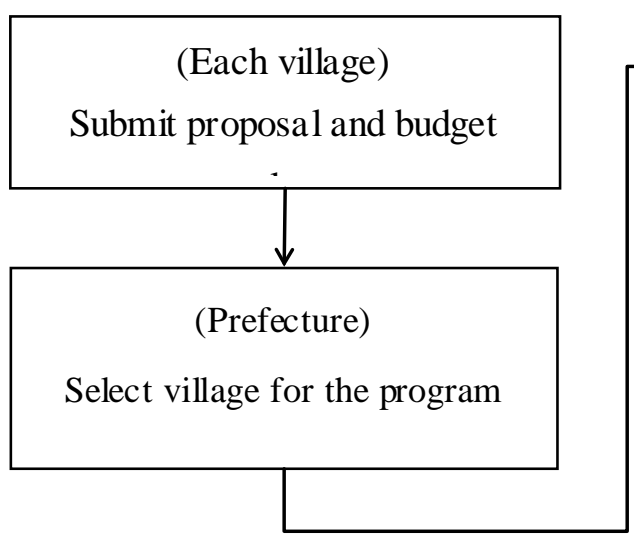

(After selection)

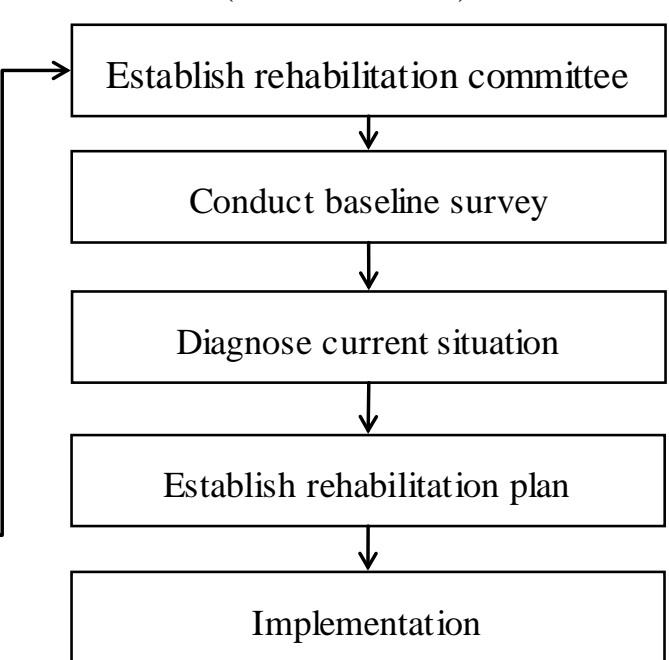

Figure 1. Procedure for establishing a rehabilitation plan under the Economic Rehabilitation Movement

Year $=1930$
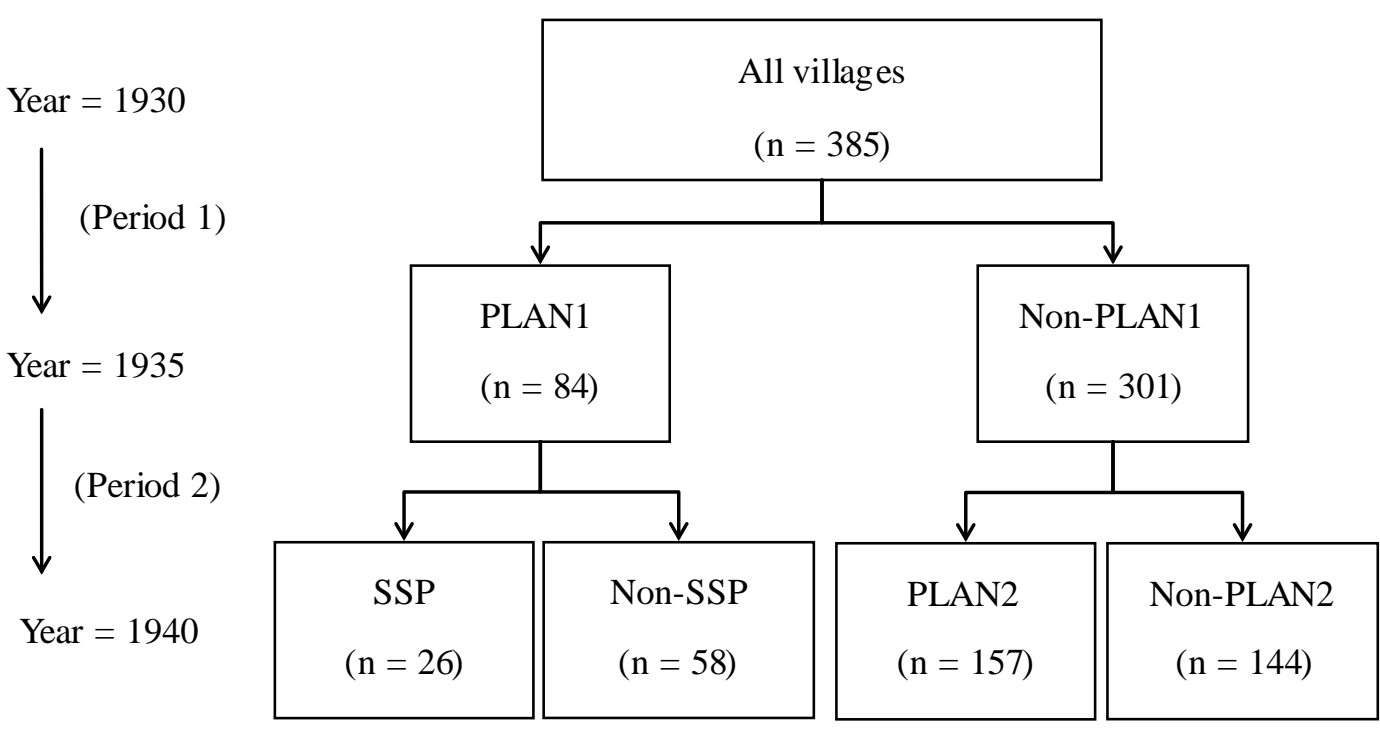

Figure 2. Study samples and periods 